\title{
Antibacterial Activities of Seaweed (Eucheuma cottonii) Extract Against Escherichia coli Bacteria
}

\author{
(Aktivitas Antibakteri Ekstrak Rumput Laut (Eucheuma cottonii) \\ Terhadap Bakteri Escherichia Coli) \\ Sukmawati ${ }^{*}$ \\ Fakultas Perikanan, Universitas Mubammadiyah Sorong, Papua Barat \\ Jl. Pendidikan, No. 27, Remu Utara, Malaingkedi, Sorong Utara, Kota Sorong, Papua 98416
}

\section{ABSTRACT}

Indonesia is a maritime country that has more than $70 \%$ of its territory dominated by oceans and is a marine area that has abundant natural resources, one of which is Eucheuma cottonii. The content of compounds by E. cottonii has many benefits, the compound content of E.cottonii is a phenolic compound (flavonoids). Flavonoids found in seaweed E. cottonii are secondary metabolite compounds that can produce antibacterial activity. The purpose of this study was to determine the antibacterial activity of seaweed extract (E. cottonii) against Escherichia coli bacteria. The method that has been used in this research is descriptive method, including extraction, maceration, antibacterial activity test. The results of this study stated that the antibacterial activity of E. cottonii seaweed extract was able to inhibit the growth of E. coli bacteria. The highest antibacterial activity was found at a concentration of $50 \%$ ppm dry extract solution with a methanol solvent of $3.3 \mathrm{~mm}$ while the lowest antibacterial activity was found at a concentration of $5 \%$ ppm wet extract solution with a methanol solvent whose inhibitory activity value was $0.1 \mathrm{~mm}$. Furthermore, the antibacterial activity test for positive control showed a strong inhibitory value of $7.8 \mathrm{~mm}$, while the negative control did not indicate any inhibitory value against E. coli bacteria.

Indonesia adalah negara maritim yang memiliki lebih dari 70\% wilayahnya didominasi oleh lautan dan merupakan kawasan bahari yang memiliki sumber daya alam yang melimpah, salah satunya adalah Eucheuma cottonii. Kandungan senyawa yang dimiliki oleh E. cottonii memiliki banyak manfaat, kandungan senyawa pada E. cottonii adalah senyawa fenolik (flavonoid). Flavonoid yang ditemukan dalam rumput laut E. cottonii adalah senyawa metabolit sekunder yang dapat menghasilkan aktivitas antibakteri. Tujuan dari penelitian ini adalah untuk mengetahui aktivitas antibakteri dari ekstrak rumput laut (E. cottonii) terhadap bakteri Escherichia coli. Metode yang telah digunakan dalam penelitian ini adalah metode deskriptif, termasuk ekstraksi, maserasi, tes aktivitas antibakteri. Hasil dari penelitian ini dinyatakan bahwa aktivitas antibakteri ekstrak rumput laut E. cottonii mampu menghambat pertumbuhan bakteri E. coli. Aktivitas antibakteri tertinggi ditemukan pada konsentrasi larutan ekstrak kering 50\% ppm dengan pelarut metanol 3,3 mm sedangkan aktivitas antibakteri terendah ditemukan pada konsentrasi larutan ekstrak basah 5\% ppm dengan pelarut metanol yang nilai aktivitas penghambatannya $0,1 \mathrm{~mm}$. Selanjutnya pada uji aktivitas antibakteri untuk kontrol positif menunjukkan nilai daya hambat yang kuat sebesar $7.8 \mathrm{~mm}$, sedangkan pada kontrol negatif tidak menunjukkan adanya nilai daya hambat terhadap bakteri E.coli.

Keywords: Antibacterial, Eucheuma cottonii extract, Escherichia coli.

*)Corresponding author:

Sukmawati

E-mail: sukmawati.sw91@gmail.com

\section{PENDAHULUAN}

Indonesia merupakan negara maritim dengan lebih dari $70 \%$ permukaan buminya didominasi oleh lautan. Bahan alam bahari banyak dimanfaatkan dalam bidang pertanian (pangan), industri, kesehatan, dan lingkungan yang umumnya bersumber dari organisme hayati. Banyak senyawa aktif yang diisolasi dari bahan alam bahari seringkali dapat menimbulkan efek signifikan terhadap organisme lain dalam masyarakat organisme bahari. Senyawa aktif tersebut dapat berupa bioaktif atau pun biotoksin [1]. 
Kandungan senyawa yang dimiliki Eucheuma cottonii antara lain adalah senyawa fenolik (flavonoid) dan senyawa steroid/triterpenoid. Flavonoid ialah senyawa yang mengandung inti aromatic khusus dan secara luas tersebar pada tanaman [2]. Flavonoid yang terdapat pada rumput laut E. cottonii merupakan senyawa metabolit sekunder yang memiliki kemampuan dalam menghambat aktivitas antibakteri [3]. Antibakteri merupakan zat yang berfungsi membunuh atau menekan pertumbuhan dan reproduksi bakteri [4]. Berdasarkan aktivitas zat antibakteri dapat bersifat bakterisidal (membunuh bakteri), dan bakteriostatik (menghambat pertumbuhan bakteri).

Senyawa flavonoid tersebut dapat menghambat pertumbuhan bakteri patogen penyebab keracunan dan penyakit pada manusia, seperti bakteri Escherichia coli dan Staphylococcus aureus.

Beberapa bakteri seperti Escherichia coli, Vibrio cholera, Salmonella typhosa, dan Staphylococcus aureus merupakan bakteri indikator pencemaran di laut yang dapat menimbulkan berbagai macam penyakit bagi makhluk hidup. Bakteri Escherichia coli merupakan bakteri normal yang terdapat pada usus yang seringkali menyebabkan infeksi [5].

E. coli merupakan salah-satu bakeri indikator yang sering digunakan dalam uji mikroba. Aktivitas antibakteri dapat diketahui dengan melakukan uji zona hambat melalui proses ekstraksi. Ekstraksi merupakan proses yang secara selektif memisahkan beberapa senyawa bioaktif dengan bantuan pelarut. Salah satu faktor penting yang menentukan keberhasilan ekstraksi dalam menggunakan pelarut ialah penggunaan jenis pelarut yang digunakan. Jenis pelarut akan mempengaruhi jenis senyawa bioaktif yang diekstrak sebab setiap jenis pelarut memiliki efisiensi dan selektifitas yang berbeda dalam melarutkan komponen bioaktif. Selain itu perlu memperhatikan titik didih, sifat toksik, mudah tidaknya terbakar dan sifat korosif terhadap peralatan ekstraksi. Proses perpindahan komponen bioaktif dari bahan yang diekstrak ke pelarut melalui tahap difusi.

Proses difusi merupakan perubahan secara spontan dan tidak dapat kembali lagi dari fase yang memiliki konsentrasi lebih tinggi menuju konsentrasi lebih rendah [6]. Menurut Sartika \& Purwiyanto [7] jika zona hambat yang terbentuk pada uji difusi berukuran kurang dari $5 \mathrm{~mm}$, maka aktivitas penghambatannya dikategorikan lemah, zona hambat berukuran 5-10 mm dikategorikan sedang, 10-19 mm dikategorikan kuat dan $20 \mathrm{~mm}$ atau lebih dikategorikan sangat kuat. Berdasarkan dari hasil studi pustaka maka perlu dilakukan pengujian ekstrak rumput laut yang berasal dari perairan kepulauan Sorong, dengan tujuan penelitian ialah untuk mengetahui aktivitas anti bakteri ekstrak rumput laut (E.cottonii) terhadap bakteri E. coli.

\section{METODE PENELITIAN}

Metode penelitian yang digunakan merupakan penelitian deskriptif dengan melihat daya aktivitas anti bakteri ekstrak rumput laut dengan mengukur zona hambat yang terbentuk pada cawan sampel. Pengambilan sampel rumput laut dilakukan dengan menggunakan metode sampling purposive.

Rumput laut yang diperoleh dari perairan kota Sorong dikumpulkan dalam plastik sampel. Rumput laut dibersihkan dari pengotor yang melekat kemudian dicuci dengan air mengalir. Rumput laut dikeringkan dengan cara diangin-anginkan namun tidak boleh langsung terkena cahaya matahari karena akan mempengaruhi kandungan senyawa yang terdapat dalam rumput laut.

Ekstraksi senyawa metabolit sekunder dilakukan dengan cara ekstraksi maserasi dengan pelarut methanol dan akuades. Prosedur ekstraksi mengacu pada metode Deshusses, et al., [8]. Larutan ekstrak rumput laut yang digunakan dalam penelitian ini digunakan konsentrasi $50 \%$ ppm, 45\% ppm, 40\% ppm, 35\% ppm, 30\% ppm, 25\% ppm, 20\% ppm, 15\% $\mathrm{ppm}, 10 \% \mathrm{ppm}$ dan $5 \% \mathrm{ppm}$. Jenis pelarut yang digunakan ialah metanol 90\%.

Perlakuan dalam penelitian uji aktivitas antibakteri antara lain uji kontrol positif, uji kontrol negatif dan uji aktivitas antibakteri eksrak rumput laut E. cottonii. Uji kontrol positif dilakukan dengan menggunakan antibiotik ampisilin. Uji kontrol negatif dilakukan dengan menggunakan pelarut akuades. Uji ekstrak rumput laut kering dan ekstrak rumput laut basah masing-masing menggunakan pelarut methanol $90 \%$. Metode yang digunakan pada uji ini adalah metode sumuran.

Analisis data dihitung, dengan pengukuran zona bening yang terbentuk pada media isolate bakteri uji yang telah didifusikan dengan antibakteri ekstrak rumput laut E. cottonii, dengan menggunakan rumus berikut: 
Indeks Zona hambat : $\frac{a-b}{b}$

Keterangan :

a: Diameter Zona bening

b: Diameter sumuran

[9].

\section{HASIL DAN PEMBAHASAN}

Hasil penggunaan ekstrak E. cottonii pada metode sumuran dengan menggunakan methanol sebagai pelarut menunjukkan adanya aktivitas antibakteri terhadap E. coli (Tabel 1 dan Gambar 1-Gambar 10).

Tabel 1. Hasil pengamatan aktivitas antibakteri ekstrak rumput laut E. cottonii terhadap bakteri E. coli dengan penggunaan konsentrasi yang berbeda

\begin{tabular}{ccccccc}
\hline \multicolumn{3}{c}{ Jenis Ekstrak* (mm) } & & $\begin{array}{c}\text { Kont } \\
\text { rol } \\
+\end{array}$ & $\begin{array}{c}\text { Kon } \\
\text { trol } \\
-\end{array}$ \\
\hline $\begin{array}{c}\text { Konsentrasi } \\
(\%) \text { ppm }\end{array}$ & EKM & EBM & EKA & EBA & & \\
\hline 50 & 3.3 & 3.0 & 0 & 0 & & \\
45 & 2.5 & 2.5 & 0 & 0 & & \\
40 & 2.5 & 2.0 & 0 & 0 & & \\
35 & 2.5 & 2.0 & 0 & 0 & & \\
30 & 1.4 & 1.2 & 0 & 0 & 7.8 & 0 \\
25 & 1.4 & 1.2 & 0 & 0 & & \\
20 & 1.4 & 1.2 & 0 & 0 & & \\
15 & 1.4 & 1.0 & 0 & 0 & & \\
10 & 1.0 & 0.6 & 0 & 0 & & \\
5 & 0.8 & 0.1 & 0 & 0 & & \\
\hline
\end{tabular}

\section{*Keterangan:}

EKM : Ekstrak kering Eucheuma cottonii + methanol $90 \%$ EBM : Ekstrak Basah Eucheuma cottonii + metanol $90 \%$ EKA : Ekstrak Kering Eucheuma cottonii + Akuades EBA :Ekstrak basah Eucheuma cottonii + Akuades $\mathrm{K}+$ : Ampisilin

$\mathrm{K}-$ : Akuades

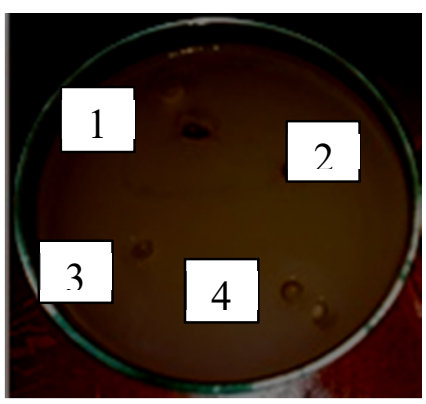

Gambar 1. (Aktivitas antibakteri Eucheuma cottonii terhadap bakteri E. coli pada konsentrasi 50\% ppm (1). EKM; (2). EBM; (3). EKA; (4). EBA)

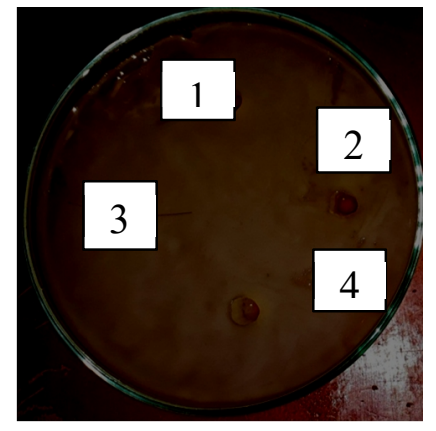

Gambar 2. (Aktivitas antibakteri Eucheuma cottonii terhadap bakteri E. coli pada konsentrasi 45\% ppm (1). EKM; (2). EBM; (3). EKA; (4). EBA)

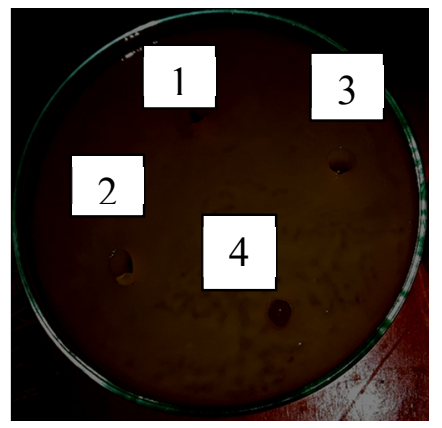

Gambar 3. (Aktivitas antibakteri Eucheuma cottonii terhadap bakteri E. coli pada konsentrasi 40\% ppm (1). EKM; (2). EBM; (3). EKA; (4). EBA

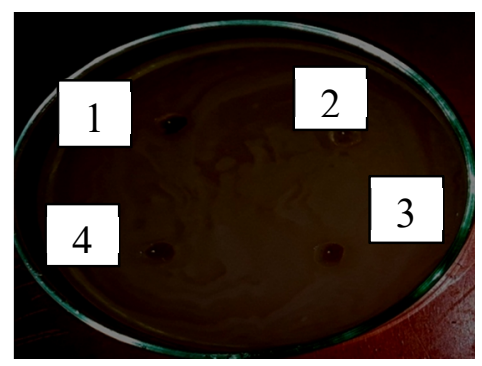

Gambar 4. (Aktivitas antibakteri Eucheuma cottonii terhadap bakteri E. coli pada konsentrasi 35\% ppm (1). EKM; (2). EBM; (3). EKA; (4). EBA 


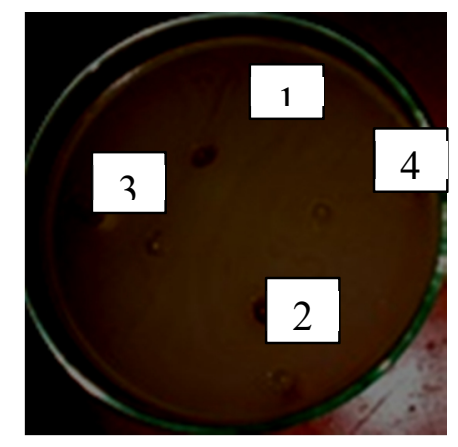

Gambar 5. (Aktivitas antibakteri Eucheuma cottonii terhadap bakteri E. coli pada konsentrasi 30\% ppm (1). EKM; (2). EBM; (3). EKA; (4). EBA

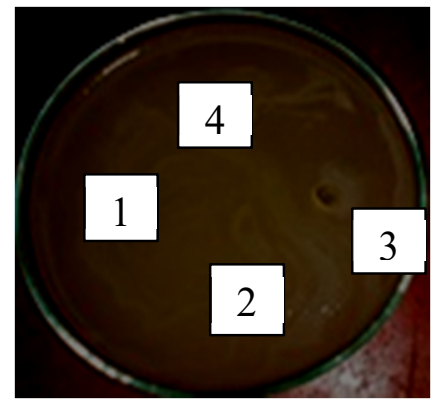

Gambar 6. (Aktivitas antibakteri Eucheuma cottonii terhadap bakteri E. coli pada konsentrasi 25\% ppm (1). EKM; (2). EBM; (3). EKA; (4). EBA

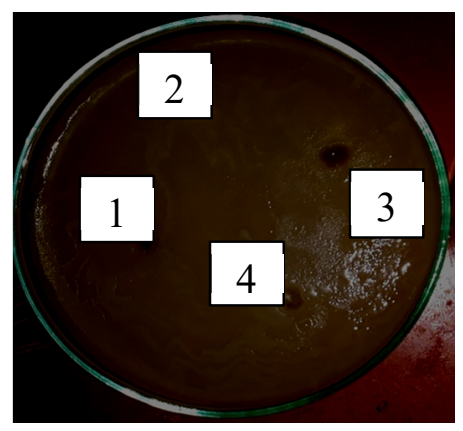

Gambar 7. (Aktivitas antibakteri Eucheuma cottonii terhadap bakteri E. coli pada konsentrasi 20\% ppm (1). EKM; (2). EBM; (3). EKA; (4). EBA

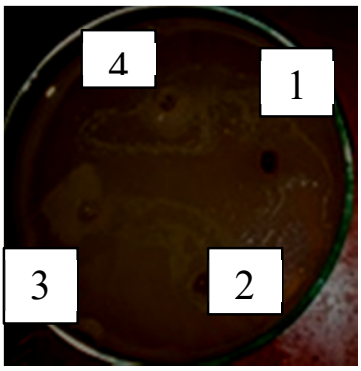

Gambar 8. (Aktivitas antibakteri Eucheuma cottonii terhadap bakteri E. coli pada konsentrasi 15\% ppm (1). EKM; (2). EBM; (3). EKA; (4). EBA

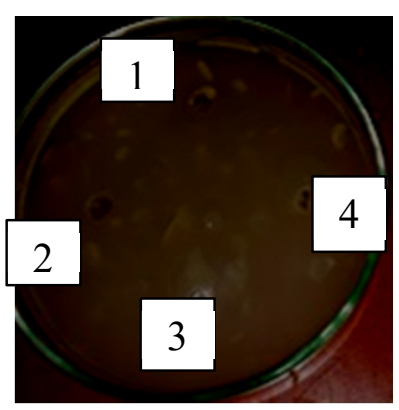

Gambar 9. (Aktivitas antibakteri Eucheuma cottonii terhadap bakteri E. coli pada konsentrasi 15\% ppm (1). EKM; (2). EBM; (3). EKA; (4). EBA

Hasil ekstrak dari ke 10 konsentrasi ekstrak sampel berbeda yang diuji terhadap bakteri E. coli menunjukkan bahwa terdapat aktivitas antibakteri dengan kisaran nilai untuk ekstrak kering methanol antara $3.3 \mathrm{~mm}-0,8 \mathrm{~mm}$. Nilai tertinggi terdapat pada sampel dengan konsentrasi 50\% ppm larutan ekstrak Eucheuma cottonii dengan nilai daya hambat hambat sebesar $3.3 \mathrm{~mm}$ dan terendah pada konsentrasi 5\% ppm larutan ekstrak Eucheuma cottonii dengan nilai hambat $0.8 \mathrm{~mm}$. Sedangkan nilai hambat ekstrak basah rumput laut terhadap E. coli pada konsentrasi larutan ekstrak 50\% ppm dengan nilai hambat paling tinggi sebesar $3.0 \mathrm{~mm}$ dan nilai hambat terendah $0.1 \mathrm{~mm}$. 


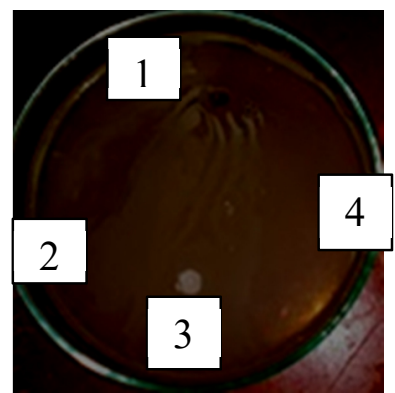

Gambar 10. (Aktivitas antibakteri terhadap bakteri E. coli (1). Kontrol positif (Ampisilin); (2). Kontrol negative (Akuades)

Penggunaan ekstrak, baik larutan ekstrak kering E. cottonii maupun larutan ekstrak basah E. cottonii menunjukkan bahwa nilai hambat terhadap E. coli berbanding lurus dengan jumlah konsentrasi larutan ekstrak yang digunakan, yang mana semakin tinggi nilai konsentrasi maka nilai hambat terhadap E. coli juga semakin besar. Dalam penelitian ini nilai hambat larutan ekstrak E.cottonii masih tergolong lemah karena nilai hambatnya masih di bawah $5 \mathrm{~mm}$ [7]. Selain daripada itu untuk menentukan nilai hambat yang baik dan efektif, maka nilai hambat dan konsentrasi larutan ekstrak yang digunakan harus berbanding terbalik, yang artinya semakin tinggi nilai daya hambat terhadap bakteri uji maka yang diperlukan semakin kecil nilai konsentrasi larutan ekstrak yang digunakan.

Sedangkan nilai hambat ekstrak E. cottonii dengan penggunaan pelarut akuades tidak menunjukkan adanya kemampuan dalam menghambat bakteri E. coli.

Berbanding terbalik dengan larutan ekstrak rumput laut yang menggunakan pelarut metanol. Menurut Septiani \& Asnani [10] pelarut metanol merupakan pelarut yang memiliki sifat polar, pelarut methanol tersebut berfungsi untuk mereduksi senyawa senyawa fitokimia yang bersifat polar seperti terpenoid yang memiliki kemampuan sebagai antibakteri. Menurut Dolorossa [3], E. cottonii memiliki kandungan senyawa metabolit sekunder berupa senyawa flavonoid yang memiliki kemampuan dalam membentuk senyawa kompleks dengan protein sel bakteri melalui ikatan hidrogen, sehingga struktur dinding sel dan membran sitoplasma bakteri yang mengandung protein menjadi tidak stabil. Selanjutnya protein sel bakteri menjadi kehilangan keseimbangan dalam proses metabolismenya. Sehingga mengakibatkan fungsi permeabilitas sel pada bakteri terganggu kemudian sel bakteri akan mengalami lisis yang mengakibatkan pada kematian sel bakteri [11].
Aktivitas antibakteri E. cottonii tergolong masih rendah, baik ekstrak kering maupun ekstrak basah dari E. cottonii, hal tersebut dapat dipengaruhi karena penggunaan ekstrak masih berupa ekstrak kasar, teknik pembuatan ekstrak, maupun bakteri uji.

\section{KESIMPULAN}

Aktivitas antibakteri ekstrak rumput laut E. cottonii terhadap bakteri E. coli, dapat disimpulkan bahwa aktivitas antibakteri ekstrak rumput laut E. cottonii mampu menghambat pertumbuhan bakteri E. coli. aktivitas antibakteri yang tertinggi terdapat pada konsentrasi 50\% ppm larutan Ekstrak kering dengan pelarut metanol yaitu sebesar $3.3 \mathrm{~mm}$ sedangkan aktivitas antibakteri yang terendah terdapat pada konsentrasi 5\% ppm larutan ekstrak basah dengan pelarut methanol yang nilai aktivitas hambatnya 0.1 mm. Selanjutnya pada uji aktivitas antibakteri untuk kontrol positif menunjukkan nilai daya hambat yang kuat sebesar $7.8 \mathrm{~mm}$, sedangkan pada kontrol negatif nilai daya hambatnya $0 \mathrm{~mm}$ terhadap bakteri E.coli.

\section{DAFTAR PUSTAKA}

[1] Duan, F., Yu, Y., Liu, Z., Tian, L., \& Mou, H. (2016). An effective method for the preparation of carrageenan oligosaccharides directly from Eucheuma cottonii using cellulase and recombinant $x$ carrageenase. Algal research, 15, 93-99.

[2] Patel, V. R., Patel, P. R., \& Kajal, S. S. (2010). Antioxidant activity of some selected medicinal plants in western region of India. Advances in Biological research, 4(1), 23-26.

[3] Dolorosa, T. M., Nurjanah, P. S., Effionora, A., \& Taufik, H. (2017). Kandungan senyawa bioaktif bubur rumput laut Sargassum plagyophyllum dan Eucheuma cottonii sebagai bahan baku krim pencerah kulit. Jurnal Pengolahan Hasil Perikanan Indonesia, 20(3), 633-644.

[4] Angraini, E., Angraeni, D. N., Umami, S. S., Sumiati, E., \& Taufiqurokhman, T. (2019, February). Antagonism of Lentinus Cladopus Lc4 Extract, Trichoderma sp. Jpa Extract on Bacillus sp., Xanthomonas sp. and E. Coli. In Journal of Physics: Conference Series (Vol. 1155, No. 1, p. 012057). IOP Publishing.

[5] Endriani, R., Andrini, F., \& Alfina, D. (2010). Pola resistensi bakteri penyebab infeksi saluran kemih (ISK) terhadap antibakteri di pekanbaru. Jurnal Natur Indonesia, 12(02), 130-135. 
[6] Nurainy, F., Rizal, S., \& Yudiantoro, Y. (2012). Pengaruh Konsentrasi Kitosan Terhadap Aktivitas Antibakteri Dengan Metode Difusi Agar (Sumur. Jurnal Teknologi \& Industri Hasil Pertanian, 13(2), 117-125.

[7] Sartika, R., \& Purwiyanto, A. I. (2013). Aktivitas antibakteri ekstrak rumput laut Eucheuma cottoni terhadap bakteri Escherichia coli, Staphylococcus aureus, Vibrio cholera dan Salmonella typhosa. Maspari Journal, 5(2), 98-103.

[8] Deshusses, J. M., Burgess, J. A., Scherl, A., Wenger, Y., Walter, N., Converset, V., \& Sanchez, J. C. (2003). Exploitation of specific properties of trifluoroethanol for extraction and separation of membrane proteins. Proteomics: International Edition, 3(8), 14181424.

[9] Sukmawati, S. (2018). Isolasi Bakteri Selulolitik dari Limbah Kulit Pisang. Biotropic: The Journal of Tropical Biology, 2(1), 46-52.

[10] Septiana, A. T., \& Asnani, A. (2012). Kajian sifat fisikokimia ekstrak rumput laut coklat Sargassum duplicatum menggunakan berbagai pelarut dan metode ekstraksi. Agrointek: Jurnal Teknologi Industri Pertanian, 6(1), 22-28.

[11] Martini, N. D., Katerere, D. R. P., \& Eloff, J. N. (2004). Biological activity of five antibacterial flavonoids from Combretum erythrophyllum (Combretaceae). Journal of ethnopharmacology, 93(2-3), 207-212. 